\title{
Effect of Packaging Conditions on Shelf-Life of Mortadella Made with Citrus Fibre Washing Water and Thyme or Rosemary Essential Oil
}

\author{
Manuel Viuda-Martos, Yolanda Ruiz-Navajas, Juana Fernández-López, José Angel Pérez-Álvarez.
}

IPOA Research Group (UMH-1 and REVIV-Generalitat Valenciana). AgroFood Technology Department. Miguel Hernández University, Alicante, Spain.

E-mail: mviuda@umh.es

Received October, $12^{\text {th }}, 2010$; revised November $29^{\text {th }}, 2010$; accepted December $13^{\text {th }}, 2010$.

\begin{abstract}
The "elimination" of chemical additives used in a wide variety of foods is demanded, while "natural" additives are seen as a benefit for both quality and safety. Researchers are looking for new sources of ingredients and/or additives. The aim of this work was to study the effect of 1) the addition of $5.00 \%$ citrus fibre washing water (CFWW) and $0.02 \%$ rosemary essential oil (REO) or $0.02 \%$ thyme essential oil (TEO) and 2) storage conditions on the chemical, microbeological and sensorial properties of mortadellas, a bologna-type sausage. CFWW $+R E O$ or CFWW + TEO samples stored in vacuum packaging showed the lowest TBA values. The resulting products were packed either in vacuum, modified atmosphere or air pouches and stored for 24 days. Lipid oxidation was assessed by the TBA method, while a quantitative descriptive analysis was carried out for sensory evaluation. Microbiological counts were also determined. $C F W W+R E O$ samples stored in vacuum packaging showed the lowest counts of aerobic and lactic acid bacteria. The sensory evaluation provided similar scores for CFWW + REO and CFWW + TEO samples. The lowest scores were obtained for control mortadella stored in air packaging. The addition of citrus fibre washing water and spice essential oils is a technologically viable alternative in emulsified meat products, since they improve customer acceptance and have desirable effects as regards oxidative stability and reduced microbial growth, which contributes to prolonging their shelf-life.
\end{abstract}

Keywords: Essential Oils, Cooked Meat, Co-Products, Shelf-Life

\section{Introduction}

The industrial transformation of fruits generates large quantities of co-products rich in bioactive compounds that may well be suitable for other purposes [1]. Some of these products have been recognized by several organizations (FDA and EFSA) as possessing proven health benefits. Depending on the availability of a suitable technology, these co-products can be converted into commercial products for use as raw materials for secondary processes (intermediate foods ingredients), as operating supplies, or as ingredients in new products [2]. From a technological and scientific point of view, many of these bioactive compounds present in the co-products have been shown to have a beneficial role on human health [3]; improving the physiological functions of the organism and permitting the design and optimisation of foods that prevent or diminish the risk of certain chronic diseases [4]. It has been estimated that $5.00 \%$ of the foods consumed in Europe could be classified as functional [5].

The addition of ingredients rich in bioactive compounds may have a technological purpose too: mainly the inhibition of lipid oxidation, a very important property especially in meat products. Natural and synthetic antioxidants have been commonly used to inhibit the development of oxidative reactions in meat products [6] such as dried herbs and essential oils, have also been successfully used to reduce lipid oxidation in the same products [7].

The process of obtaining dietary fibre from orange juice co-products also generates a series of co-products, among them the washing water used since the process uses large quantities of water, an aspect which, besides being of economic importance, is important from an environmental point of view [8]. One way of minimizing the consequences of this problem would be to re-use the 
water used in the above washing process, since it still contains many compounds potentially beneficial both from a technological and health-related point of view and, once "treated", it could be re-used to reduce overall water consumption [1].

One component present in aromatic plants and spices, and which may act as a natural antioxidant, is the corresponding essential oil. In general terms, essential oils are composed of $>70$ components, principally polyphenols, terpenes, monoterpenes and sesquiterpenes, and are responsible for many of their functional (antioxidant, antibacterial, anti-inflammatory, anti-ulcerous, anti-carcinogenic, etc.) properties [9]. Nowadays, essential oils and their components are gaining increasing attention because of their relatively safe status, their wide acceptance by consumers, and their potential multi-purpose functional uses [10]. Spice essential oils, added at suitable concentrations, do not change the sensory properties (color, taste or flavor) of the food matrix in which they are incorporated as supplement [11].

The aim of this work was to study the effect of 1) the addition of citrus fibre washing water (CFWW) and rosemary essential oil (REO) or thyme essential oil (TEO) and 2) storage conditions (air, modified atmosphere and vacuum packed) on the chemical, microbiological and sensorial properties of mortadellas, a bologna-type sausage. Traditional formula was used as control sample and experimental mortadellas contained $5.00 \% \mathrm{CFWW}$ and $0.02 \%$ REO or $0.02 \%$ TEO.

\section{Materials and Methods}

\subsection{Sausage Manufacture}

Mortadellas were manufactured according to a traditional formula (only the meat percentage adds up to $100.00 \%$ while the percentage of the other ingredients are related to the meat): $50.00 \%$ lean pork meat and $50.00 \%$ pork backfat; $15.00 \%$ water (ice, w/w), $3.00 \%$ potato starch $(\mathrm{w} / \mathrm{w}), 2.50 \%$ sodium chloride $(\mathrm{w} / \mathrm{w}), 300$ $\mathrm{mg} / \mathrm{kg}$ sodium tripolyphosphate, $500 \mathrm{mg} / \mathrm{kg}$ sodium ascorbate, $150 \mathrm{mg} / \mathrm{kg}$ sodium nitrite, spices $(0.01 \%$ black pepper, $0.005 \%$ nutmeg and $0.2 \%$ garlic powder). This original mixture was used as control, while to assess the influence of the concentration of the citrus fibre washing water (CFWW), and thyme (TEO) or rosemary (REO) essential oil, the water content $(5 \%)$ of the control formula was replaced by CFWW (5.00\%) and TEO or REO were added $(0.02 \%)$. The citrus fibre washing water was obtained by the method described by Fernández-Ginés et al. [12] and thyme and rosemary essential oils were supplied by Ravetllat Aromatics (Barcelona, Spain).

The products were prepared in the IPOA research group pilot plant, using industrial processing techniques.
Frozen raw material of animal origin, except pork backfat, were transferred to the cutter (Tecator 1094 Homogeneizer, Tekator, Höganäs, Sweden) with the sodium chloride to extract salt-soluble proteins; after comminution, the other ingredients and additives were added. The pork backfat, previously divided into $10 \times 10 \times 10 \mathrm{~cm}$ cubes, was then added. After homogenization, the mixture was stuffed into Fibran-Pack (Fibran, Girona, Spain) artificial casing $100 \times 150 \mathrm{~mm}$ long, clipped at both ends (Polyclip system/Niedecker, Germany) and cooked in a water bath. The mortadellas were kept in the bath until the coldest point reached $72^{\circ} \mathrm{C}$ (geometric centre of each mortadella, which corresponds to the thickest part of the product). A thermocouple probe (Omega Engineering, Inc., Stamford, CT, USA) positioned in the geometric centre of the mortadella was used to monitor product temperature. When the endpoint temperature was achieved, the sausages were immediately chilled on ice. After reaching room temperature, the product was transferred to the laboratory in insulated boxes containing ice. The sausages $\left(500 \mathrm{~g}\right.$ each) were stored at $4^{\circ} \mathrm{C}$ until analysis.

\subsection{Storage Conditions}

Immediately after the mortadella manufacturing process had finished, twenty slices $(1.5 \mathrm{~cm}$ thick) were asepticcally taken from each sausage. The trays containing the slices were packed either in vacuum, modified atmosphere (MA) $\left(80.00 \% \mathrm{~N}_{2}\right.$ and $\left.20.00 \% \mathrm{CO}_{2}\right)$ or air pouches made of polyethylene and polyamide laminate of $1.1 \mathrm{~g} /$ $\mathrm{m}^{2} / 24 \mathrm{~h}$ water vapour permeability at $23^{\circ} \mathrm{C}, 10 \mathrm{~cm}^{3} / \mathrm{m}^{2}$ $/ 24 \mathrm{~h}$ nitrogen permeability at $23^{\circ} \mathrm{C}, 140 \mathrm{~cm}^{3} / \mathrm{m}^{2} / 24 \mathrm{~h}$ carbon dioxide permeability at $23^{\circ} \mathrm{C}$, and $30 \mathrm{~cm}^{3} / \mathrm{m}^{2} / 24$ $\mathrm{h}$ oxygen permeability at $23^{\circ} \mathrm{C}$ (Fibran, Girona, Spain). The pouches were heat-sealed and stored at $4 \pm 1{ }^{\circ} \mathrm{C}$ in a cabinet simulating supermarket retail conditions. The cabinet was illuminated by a standard supermarket fluorescent lamp (OSRAM, Germany). All the samples were exposed to continuous light of 1000 lux at the surface, measuring the light intensity using a Lutron LX-102 luxometer (Taiwan). The positions of the samples in the cabinet were rotated every $24 \mathrm{~h}$ to minimize light intensity differences and possible temperature variations at the surface of the mortadellas. The packs were stored for 24 days Samples from each treatment and storage condition were taken at $0,6,12,18$, and 24 days (storage time) and analyzed on the same day.

\subsection{Physico-chemical Analysis}

The CIE LAB color space was selected for colour determination. The following colour coordinates were determined: lightness $\left(\mathrm{L}^{*}\right)$, redness $\left(\mathrm{a}^{*}, \pm\right.$ red-green), and yellowness $\left(b^{*}, \pm\right.$ yellow-blue). Colour determinations 
were made, at $12 \pm 2^{\circ} \mathrm{C}$ by means of a Minolta CM-2002 (Minolta Camera Co., Osaka, Japan) spectrophotometer with illuminant $\mathrm{D}_{65}, 10^{\circ}$ observer angle, $11 \mathrm{~mm}$ aperture for illumination and $8 \mathrm{~mm}$ for measurement. American Meat Science Association guidelines for colour measurements were followed and spectrally pure glass (CRA51, Minolta Co., Osaka, Japan) was placed between the samples and the equipment [13].

The $\mathrm{pH}$ was measured by blending a $5 \mathrm{~g}$ sample with $50 \mathrm{~mL}$ deionised water for $2 \mathrm{~min}$. The $\mathrm{pH}$ of the resultant suspension was measured with a Crison $\mathrm{pH}$ meter (Model 507, Crison, Barcelona, Spain), equipped with a Crison combination electrode (Cat. nr 52, Crison, Barcelona, Spain).

Texture profile analysis (TPA) was performed with a TA-XT2 Texture Analyser (Stable Micro Systems, Surrey, England). Mortadella samples were removed from the casing, cut into cubes $(1 \times 1 \times 1 \mathrm{~cm})$ and subjected to a 2-cycle compression test. All instrumental texture analyses were conducted on chilled $\left(4^{\circ} \mathrm{C}\right)$ samples. The samples were compressed to $70.00 \%$ original height through a 2-bite mechanism at a compression load of $25 \mathrm{~kg}$, and a cross-head speed of $20 \mathrm{~cm} / \mathrm{min}$. The texture profile was determined as described by Bourne [14].

\subsection{Lipid Oxidation}

Lipid oxidation was assessed in triplicate by the 2-thiobarbituric acid (TBA) test following the recommendations of Buege and Aust [15]. TBARS values were calculated from a standard curve of malonaldehyde (MAD) and expressed as $\mathrm{mg} \mathrm{MAD} / \mathrm{kg}$ sample.

\subsection{Determination of Polyphenolic Compounds}

Samples $(2 \mathrm{~g})$ were weighed into a test tube and $6 \mathrm{~mL}$ of dimethylsulfoxide (DMSO) were added. The mixture was vigorously shaken for 2 min and left for $2 \mathrm{~h}$ in an ultrasonic water bath without temperature control. Then, the mixture was filtered through an Albet nylon filter (Albet, Barcelona, Spain) of $45 \mu \mathrm{m}$ of pore before HPLC analysis. The HPLC analysis was performed using a Hewlett Packard HP-1100 instrument (Woldbronn, Germany) equipped with a photodiode array detector and a C-18 column (Lichrosphere, RP-18 250 x 4 mm, Agilent, Woldbronn, Germany) at $T=30^{\circ} \mathrm{C}$. Phenolic compounds were analyzed in standard and sample solutions using gradient elution at $1 \mathrm{~mL} / \mathrm{min}$ with a gradient program of 0.00-20.00 $\min 95.00-75.00 \%$ A, 20.00-40.00 $\mathrm{min}$ $75.00-50.00 \%$ A, $40.00-50.00 \min 50.00-20.00 \%$ A, $50.00-60.00 \min 20.00 \%$ A. Using $2.50 \%$ acetic acid in water as solvent A and acetonitrile as solvent B.

\subsection{Sensory Evaluation}

Non-trained panellists (15 men and 15 women, aged
18-40 years) were recruited from the staff and students of the Miguel Hernández University, Alicante, Spain. Panellists were chosen on the basis of previous experience in consuming traditional mortadellas. Furthermore, a preparatory session was held prior to testing, so that each panel could thoroughly discuss and clarify each attribute to be evaluated the products. Testing was initiated after the panellists agreed on the specifications. A Quantitative Descriptive Analysis was carried out [16]. All sensory work was carried out in the sensory laboratory at the University, which fulfils requirements according to the international Standards $[17,18]$. During evaluation, the panellists were situated in private booths under incandescent/fluorescent light, with an intensity of approximately 350 lux. Rectangular pieces of approximately $1.5 \times$ $2 \mathrm{~cm}$ were cut from the centre of mortadella slices and were served at room temperature [19]. Each panellist evaluated three replicates of all the treatment groups; the sample presentation order was randomized for each panellist. Unsalted crackers and room temperature water were provided between samples to cleanse the palate. The sensory attributes were measured on unstructured scales with descriptors at both ends; no standards were provided. The attributes measured and their descriptors were as follows: for "external evaluation": global appearance (from conventional mortadella appearance to unexpected appearance), colour (from extremely light to extremely dark), shine (from dull to bright), hue (from pale pink to brown), for "taste": acid taste, saltiness, and fatness (from imperceptible to extremely intense); and for "texture": hardness (from extremely soft to extremely tough), juiciness (from extremely dry to extremely moist). At the end of the test, panellists were asked to give a score for product quality from 0 to 10 .

\subsection{Microbiological Analysis}

Samples $(25 \mathrm{~g})$ were cut from the interior of the sausages with a sterile scalpel and forceps. Samples were then homogeneised with sterile $1.50 \%$ peptone water in a Stomacher 400 (Colworth, London, U.K.) for $1.5 \mathrm{~min}$.

Total viable counts were determined on Plate Count Agar, Enterobacteriaceae using Violet Red Bile Glucose Agar (VRBGA) and Lactic acid bacteria (LAB) were counted on double layer MRS Agar at $\mathrm{pH}$ 5.6. In all cases, plates were incubated at $35^{\circ} \mathrm{C}$ for $48 \mathrm{~h}$. Psychrotrophic microbiota was determined on Plate Count Agar, and the plates were incubated at $7^{\circ} \mathrm{C}$ for $10 \mathrm{~d}$. Culture media were from Oxoid (Oxoid Unipath Ltd. Basingtoke, Hampshire, U.K.).

\subsection{Statistical Analysis}

Conventional statistical methods were used to calculate 
means and standard deviations. Statistical ANOVA analysis was applied to the data to determine differences $(\mathrm{P}<$ $0.05)$. To discover whether there were significant differences between the levels of the main factor, contrasts (Tukey test) between means were made [20]. For the mortadella shelf-life determination, ANOVAs with three factors were applied for each parameter: storage time $(0$, $6,12,18$ and 24 days), packaging conditions (vacuum, modified atmosphere and air) and treatments (control, CFWW + REO and CFWW + TEO). The Statistical analyses were made using Statgraphics 5.1 for Windows.

\section{Results and Discussion}

\subsection{Physico-chemical Analysis}

In meat products, several factors affect consumer acceptability, thus in some meats, colour is the main attribute for consumers [2, 21]. Color is a very important parameter because brightness and particular shade of pink are expected in this type of product [22]. Table 1 shows the effect on color coordinates, redness $\left(\mathrm{a}^{*}\right)$ and yellowness (b*) of adding CFWW + TEO or CFWW + REO to mortadellas stored in different packaging conditions.

As regards lightness $\left(\mathrm{L}^{*}\right)$ neither the type of packageing, treatment or storage time had any effect $(\mathrm{P}>0.05)$ on this coordinate, the $\mathrm{L}^{*}$ values ranging in the control,
CFWW + TEO and CFWW + REO samples from 64.65, 64.632 and 64.23 , respectively, at day zero to 65.7165.83 (depending on the packaging) for control sample, 65.34 - 65.40 (depending on the packaging) for CFWW + TEO and 65.28-65.34 (depending on the packaging) CFWW + REO samples at the end of the experiment. The absence of any modification in this parameter may have been due to the protective effect of the packing film against oxygen, as mentioned by Fernández-Ginés [12].

For the red-green coordinate $\left(\mathrm{a}^{*}\right)$ the type of packageing had no significant $(P>0.05)$ effect in either the control samples or those with added CFWW + TEO and CFWW + REO . The storage time, however, did have an effect, and the a* value fell in the control (from 9.30 at the outset to 6.06-6.21 at the end of the experiment, depending on the packaging) in CFWW + TEO samples (from 9.20 to 6.22-6.69, depending on the packaging) and in CFWW + REO samples (from 9.10 to 6.12-6.62, depending on the packaging). This coordinate is affected by the structural integrity of the food, the content and disposition of the pigment (water or lipid-soluble) and surface water availability [23]. As regards the composition of the food, the water/oil relations of the product also play an important role. This coordinate, whether from a positive (red) or negative (green) point of view,

Table 1. Redness $\left(a^{*}\right)$ and yellowness $\left(b^{*}\right)$ colour parameters of mortadellas formulated with citrus fibre washing water and spice essential oils, with different storage conditions, during 24 days of storage.

\begin{tabular}{|c|c|c|c|c|c|c|c|}
\hline \multirow{2}{*}{ Coordinate } & \multirow{2}{*}{ Sample } & \multirow{2}{*}{$\begin{array}{l}\text { Storage } \\
\text { conditions }\end{array}$} & \multicolumn{5}{|c|}{ Time (d) } \\
\hline & & & 0 & 6 & 12 & 18 & 24 \\
\hline \multirow{9}{*}{$a^{*}$} & Control & Air & $9.33 \pm 0.66^{\mathrm{aA}}$ & $8.31 \pm 0.29^{\mathrm{bA}}$ & $7.84 \pm 0.74^{\mathrm{bcA}}$ & $7.01 \pm 0.17^{\mathrm{cA}}$ & $6.06 \pm 0.28^{\mathrm{dA}}$ \\
\hline & Control & MA & $9.33 \pm 0.66^{\mathrm{aA}}$ & $8.43 \pm 0.66^{\mathrm{abA}}$ & $7.99 \pm 0.17^{\mathrm{bA}}$ & $7.09 \pm 0.66^{\mathrm{cA}}$ & $6.17 \pm 0.18^{\mathrm{dA}}$ \\
\hline & Control & Vacuum & $9.33 \pm 0.66^{\mathrm{aA}}$ & $8.71 \pm 0.52^{\mathrm{abA}}$ & $8.06 \pm 0.25^{\mathrm{bA}}$ & $7.19 \pm 0.25^{\mathrm{cA}}$ & $6.21 \pm 0.38^{\mathrm{dA}}$ \\
\hline & \multirow{3}{*}{$\begin{array}{l}\text { CFWW+TEO } \\
\text { CFWW+TEO } \\
\text { CFWW+TEO }\end{array}$} & Air & $9.33 \pm 0.66^{\mathrm{aA}}$ & $8.31 \pm 0.29^{\mathrm{bA}}$ & $7.84 \pm 0.74^{\mathrm{cA}}$ & $7.01 \pm 0.17^{\mathrm{cA}}$ & $6.06 \pm 0.28^{\mathrm{dA}}$ \\
\hline & & MA & $9.33 \pm 0.66^{\mathrm{aA}}$ & $8.43 \pm 0.66^{\mathrm{aA}}$ & $7.99 \pm 0.17^{\mathrm{aA}}$ & $7.09 \pm 0.66^{\mathrm{bA}}$ & $6.17 \pm 0.18^{\mathrm{cA}}$ \\
\hline & & Vacuum & $9.33 \pm 0.66^{\mathrm{aA}}$ & $8.71 \pm 0.52^{\mathrm{abA}}$ & $8.06 \pm 0.25^{\mathrm{bA}}$ & $7.19 \pm 0.25^{\mathrm{cA}}$ & $6.21 \pm 0.38^{\mathrm{dA}}$ \\
\hline & $\mathrm{CFWW}+\mathrm{REO}$ & Air & $9.20 \pm 0.20^{\mathrm{aA}}$ & $8.82 \pm 0.28^{\mathrm{abA}}$ & $8.39 \pm 0.45^{\mathrm{bA}}$ & $7.35 \pm 0.31^{\mathrm{cA}}$ & $6.22 \pm 0.23^{\mathrm{dA}}$ \\
\hline & CFWW+REO & MA & $9.20 \pm 0.20^{\mathrm{aA}}$ & $8.79 \pm 0.52^{\mathrm{abA}}$ & $8.30 \pm 0.27^{\mathrm{bA}}$ & $7.43 \pm 0.27^{\mathrm{cA}}$ & $6.55 \pm 0.21^{\mathrm{dA}}$ \\
\hline & CFWW+REO & Vacuum & $9.20 \pm 0.20^{\mathrm{aA}}$ & $8.73 \pm 0.56^{\mathrm{abA}}$ & $8.28 \pm 0.48^{\mathrm{bA}}$ & $7.50 \pm 0.33^{\mathrm{cA}}$ & $6.69 \pm 0.37^{\mathrm{dA}}$ \\
\hline \multirow{9}{*}{$\mathrm{b}^{*}$} & Control & Air & $7.27 \pm 0.49^{\mathrm{aA}}$ & $7.52 \pm 0.44^{\mathrm{aA}}$ & $7.67 \pm 0.22^{\mathrm{abA}}$ & $8.20 \pm 0.46^{\mathrm{bcA}}$ & $8.65 \pm 0.25^{\mathrm{cA}}$ \\
\hline & Control & MA & $7.27 \pm 0.49^{\mathrm{aA}}$ & $7.63 \pm 0.13^{\mathrm{aA}}$ & $8.03 \pm 0.12^{\mathrm{bA}}$ & $8.61 \pm 0.20^{\mathrm{cA}}$ & $8.68 \pm 0.20^{\mathrm{cA}}$ \\
\hline & Control & Vacuum & $7.27 \pm 0.49^{\mathrm{aA}}$ & $7.71 \pm 0.25^{\mathrm{aA}}$ & $8.07 \pm 0.09^{\mathrm{bA}}$ & $8.65 \pm 0.22^{\mathrm{cA}}$ & $8.74 \pm 0.23^{\mathrm{cA}}$ \\
\hline & CFWW+TEO & Air & $7.27 \pm 0.49^{\mathrm{aA}}$ & $7.52 \pm 0.44^{\mathrm{aA}}$ & $7.67 \pm 0.22^{\mathrm{aA}}$ & $8.20 \pm 0.46^{\mathrm{abA}}$ & $8.65 \pm 0.25^{\mathrm{bA}}$ \\
\hline & \multirow{2}{*}{$\begin{array}{l}\text { CFWW+TEO } \\
\text { CFWW+TEO }\end{array}$} & MA & $7.27 \pm 0.49^{\mathrm{aA}}$ & $7.63 \pm 0.13^{\mathrm{aA}}$ & $8.03 \pm 0.12^{\mathrm{bA}}$ & $8.61 \pm 0.20^{\mathrm{cA}}$ & $8.68 \pm 0.20^{\mathrm{cA}}$ \\
\hline & & Vacuum & $7.27 \pm 0.49^{\mathrm{aA}}$ & $7.71 \pm 0.25^{\mathrm{aA}}$ & $8.07 \pm 0.09^{\mathrm{bA}}$ & $8.65 \pm 0.22^{\mathrm{cA}}$ & $8.74 \pm 0.23^{\mathrm{cA}}$ \\
\hline & CFWW+REO & Air & $7.31 \pm 0.20^{\mathrm{aA}}$ & $7.42 \pm 0.25^{\mathrm{aA}}$ & $7.84 \pm 0.70^{\mathrm{aA}}$ & $8.31 \pm 0.30^{\mathrm{abA}}$ & $8.61 \pm 0.32^{\mathrm{ab} A}$ \\
\hline & CFWW+REO & MA & $7.31 \pm 0.20^{\mathrm{aA}}$ & $7.49 \pm 0.33^{\mathrm{aA}}$ & $7.89 \pm 0.36^{\mathrm{aA}}$ & $8.29 \pm 0.37^{\mathrm{abA}}$ & $8.55 \pm 0.19^{\mathrm{ab} A}$ \\
\hline & $\mathrm{CFWW}+\mathrm{REO}$ & Vacuum & $7.31 \pm 0.20^{\mathrm{aA}}$ & $7.51 \pm 0.28^{\mathrm{abA}}$ & $7.92 \pm 0.36^{\mathrm{bcA}}$ & $8.39 \pm 0.24^{\mathrm{cA}}$ & $8.48 \pm 0.27^{\mathrm{cA}}$ \\
\hline
\end{tabular}

For a same coordinate, values followed by the same small letter within the same line are not significantly different $(P>0.05)$ according to Tukey's Multiple Range Test,For a same coordinate, values followed by the same capital letter within the same column are not significantly different $(P>0.05)$ according to Tukey's Multiple Range Test. 
may have a linear relationship with the concentration of pigment [24].

For the yellow-blue coordinate $\left(b^{*}\right)$, the type of packaging (air, MA or vacuum) had no effect $(\mathrm{P}>0.05)$. In contrast, storage time $(24 \mathrm{~d})$ led to an increase $(\mathrm{P}<0.05)$ in this parameter both in the control samples, which increased from 7.27 at the outset to values rang- ing from 8.65 to 8.74 at the end of the experiment (depending on the packaging), in the CFWW + TEO samples from 7.27 at day zero, increasing to 8.65-8.74 at the end of the experiment (depending on the packageing) and in the samples with added CFWW + REO from 7.31 to 8.48-8.61 (depending on the packaging). The behaviour of $b^{*}$ depends to a great extent on the food matrix, and it is recognised that changes $(\mathrm{pH}$, oxidation extent, water activity, etc.) in the matrix have a great influence on this coordinate in many foods [25].

As regards $\mathrm{pH}$ values, neither the type of packaging nor treatment had any statistically significant effect $(\mathrm{P}>$ 0.05 ) on this parameter, while storage time was the most influential factor. In the control, CFWW + TEO and CFWW + REO samples, the $\mathrm{pH}$ decreased from 6.30, 6.26 and 6.28, respectively, at day zero until 6.15-6.16, 6.17-6.18 and 6.16, at the end of the experiment (depending on the packaging). The fall in $\mathrm{pH}$ coincided with the gradual growth of lactic bacteria in the samples which could be generating lactic acid, which would lead to the gradual decrease of $\mathrm{pH}$. This agrees with the observations of Dykes et al. [26] who sug gested that the decrease in $\mathrm{pH}$ during the storage of meat products is due to the action of lactic acid bacteria.

As regards the textural properties of the mortadellas, neither the type of packaging, treatment or time had any effect $(\mathrm{P}>0.05)$ on hardness, whose values in the control, CFWW + TEO and CFWW + REO samples ranged from $1417.40,1424.04$ and $1431.06 \mathrm{~g}$, respect- tively, at day zero to $1427.90-1430.30 \mathrm{~g}$ (depending on the packaging) in the control sample, 1424.65-1431.24 g (depending on the packaging) in CFWW+ TEO and 1428.32-1430.74 g (depending on the packaging) in CFWW + REO at the end of the experiment.

Cohesiveness was not affected $(\mathrm{P}>0.05)$ by $\mathrm{CFWW}+$ REO and CFWW + TEO addition, packaging or time. As regards springiness, CFWW+REO or CFWW + TEO addition and packaging had no effect $(\mathrm{P}>0.05)$. As time passed, the value of this parameter fell from $3.33 \mathrm{~mm}$ at day zero to $3.27-3.29 \mathrm{~mm}$ (depending on the packaging) on day 24 in the control samples, from $3.31 \mathrm{~mm}$ at day zero to $3.25-3.27 \mathrm{~mm}$ at the end of experiment, in the samples with added CFWW + TEO and from $3.30 \mathrm{~mm}$ at day zero to 3.26-3.27 mm (dep- ending on the packaging) on day 24 in the CFWW + REO. As in the case of hard- ness, the addition of CFWW + TEO or CFWW + REO, packaging and time had no effect $(\mathrm{P}>0.05)$ on gumminess or chewiness.

\subsection{Lipids Oxidation}

Table 2 shows the effect of adding citrus fibre washing water and spice essential oils, the packaging conditions and storage time on the lipid oxidation of mortadella. At day 0 , the CFWW + TEO and CFWW + REO samples showed lower oxidation values than the control in all three types of packaging with no statistically significant differences $(P>0.05)$ between either treatment. At day 6, the lowest oxidation values recorded were in the CFWW + TEO and CFWW + REO samples packed in vacuum (5.32 and $5.30 \mathrm{mg} \mathrm{MAD} / \mathrm{kg}$ sample respecttively), while no statistically significant differences $(P>0.05)$ were observed between the air packed samples. At day 12, both CFWW + REO and CFWW + TEO samples packed in vacuum continued to show the lowest oxidation values $(\mathrm{P}<0.05)$, while no statistically significant differences $(\mathrm{P}<0.05)$ were observed between the MA packed CFWW + TEO sample and the MA packed control sample. At day 18, the CFWW + REO and CFWW + TEO samples packed in vacuum continued to show the lowest oxidation values $(\mathrm{P}<0.05)$, while air packed control sample showed the highest oxidation values. No statisticcally significant differences $(\mathrm{P}<0.05)$ were observed between, CFWW + TEO and CFWW + REO samples packed in MA. At the end of the experiment (24 days), the vacuumpacked CFWW + REO and CFWW + TEO treated samples showed the lowest degree of oxidation $(\mathrm{P}<$ $0.05)$ of all the samples, regardless of packaging type, while both the air-packed control sample showed the highest values for this parameter.

Due to the high fat content, the comminuted nature of the raw materials and the thermal processing that such products undergo, they are prone to spoilage by lipid oxidation. The oxidative deterioration of lipid and proteins is a major concern for food technologists due to the loss of quality associated with these processes [6]. Chopping and heating may catalyze the lipid oxidation because they disrupt the cellular protective compounds contained in cell membranes such as vitamin E, electron, and hydrogen donors [27]. The lower lipid oxidation values mentioned above obtained in CFWW + TEO and CFWW + REO would be due to the protecttive effect of the same, combined with the protecttive effect of packaging which prevents any contact with oxygen that is a major oxidizing agent. The agents responsible for the antioxidant activity in both citrus fibre washing water and thyme or rosemary essential oil are the bioactive compounds they contain, and mainly, polyphenols and terpenes. 
Table 2. TBA values (mg malonaldehyde/kg sample) of mortadellas formulated with citrus fibre washing water (CFWW) and spice essential oils, with different storage conditions, during 24 days of storage.

\begin{tabular}{|c|c|c|c|c|c|c|}
\hline \multirow{3}{*}{ Sample } & \multirow{3}{*}{$\begin{array}{l}\text { Storage } \\
\text { conditions }\end{array}$} & \multicolumn{5}{|c|}{ TBA values (mg MAD kg ${ }^{-1}$ sample) } \\
\hline & & \multicolumn{5}{|c|}{ Time (d) } \\
\hline & & 0 & 6 & 12 & 18 & 24 \\
\hline \multirow{3}{*}{ Control } & Air & $4.15 \pm 0.03^{\mathrm{aA}}$ & $5.41 \pm 0.00^{\mathrm{bA}}$ & $6.01 \pm 0.00^{\mathrm{cA}}$ & $6.52 \pm 0.06^{\mathrm{dA}}$ & $7.38 \pm 0.05^{\mathrm{eA}}$ \\
\hline & MA & $4.15 \pm 0.03^{\mathrm{aA}}$ & $5.36 \pm 0.01^{\mathrm{bB}}$ & $5.89 \pm 0.00^{\mathrm{cB}}$ & $6.31 \pm 0.00^{\mathrm{dB}}$ & $6.42 \pm 0.00^{\mathrm{eB}}$ \\
\hline & Vacuum & $4.15 \pm 0.03^{\mathrm{aA}}$ & $5.34 \pm 0.00^{\mathrm{cC}}$ & $5.76 \pm 0.02^{\mathrm{cC}}$ & $6.18 \pm 0.04^{\mathrm{dC}}$ & $6.26 \pm 0.00^{\mathrm{eC}}$ \\
\hline \multirow{3}{*}{ CFWW+TEO } & Air & $4.11 \pm 0.01^{\mathrm{aA}}$ & $5.40 \pm 0.01^{\mathrm{bA}}$ & $6.00 \pm 0.01^{\mathrm{cA}}$ & $6.44 \pm 0.01^{\mathrm{dD}}$ & $7.08 \pm 0.01^{\mathrm{eD}}$ \\
\hline & MA & $4.11 \pm 0.01^{\mathrm{aA}}$ & $5.35 \pm 0.00^{\mathrm{bB}}$ & $5.88 \pm 0.01^{\mathrm{cB}}$ & $6.28 \pm 0.01^{\mathrm{dE}}$ & $6.34 \pm 0.00^{\mathrm{eE}}$ \\
\hline & Vacuum & $4.11 \pm 0.01^{\mathrm{aA}}$ & $5.32 \pm 0.00^{\mathrm{bD}}$ & $5.65 \pm 0.00^{\mathrm{cD}}$ & $6.02 \pm 0.00^{\mathrm{dF}}$ & $6.22 \pm 0.00^{\mathrm{eF}}$ \\
\hline \multirow{3}{*}{$\mathrm{CFWW}+\mathrm{REO}$} & Air & $4.11 \pm 0.00^{\mathrm{aA}}$ & $5.40 \pm 0.01^{\mathrm{bA}}$ & $6.00 \pm 0.01^{\mathrm{cA}}$ & $6.41 \pm 0.01^{\mathrm{dG}}$ & $7.00 \pm 0.01^{\mathrm{eG}}$ \\
\hline & MA & $4.11 \pm 0.00^{\mathrm{aA}}$ & $5.34 \pm 0.01^{\mathrm{bBC}}$ & $5.85 \pm 0.00^{\mathrm{cE}}$ & $6.27 \pm 0.01^{\mathrm{dE}}$ & $6.32 \pm 0.01^{\mathrm{eH}}$ \\
\hline & Vacuum & $4.11 \pm 0.00^{\mathrm{aA}}$ & $5.30 \pm 0.01^{\mathrm{bE}}$ & $5.63 \pm 0.00^{\mathrm{cF}}$ & $6.01 \pm 0.01^{\mathrm{dF}}$ & $6.22 \pm 0.00^{\mathrm{eF}}$ \\
\hline
\end{tabular}

Values followed by the same small letter within the same line are not significantly different $(P>0.05)$ according to Tukey's Multiple Range Test. Values followed by the same capital letter within the same column are not significantly different $(P>0.05)$ according to Tukey's Multiple Range Test.

The antioxidant activity of co-products obtained from the industrial manipulation of citrus fruit has been widely demonstrated in meat products, whether cooked $[1,24]$ or dry cured $[28,29]$. Such activity is basically due to their composition, especially to phenolic compounds and flavonoids. The solubility of flavonoids in fats and oils is very low and their role in the oxidation of oil is not significant; however, they can contribute to decreasing the oxidation of fat in food emulsions [30]. Thus, Finotti and Di Majo [31] reported that all flavonoids show antioxidant activity in hydrophilic environments, but this activity is reduced in lipophilic environments, as is the case with neohesperidin, hesperetin and didymin, while other flavonoids, such as naringin, narirutin or naringenin, become pro-oxidant.

The antioxidant activity of spice essential oils in general and thyme, and rosemary in particular, is generally accepted [32]. Ruberto and Baratta [33] reported that monoterpene hydrocarbons had a significant antioxidant protective effect, with several variants due to the different functional groups. Furthermore, some researchers show that some essential oils rich in nonphenolic compounds also have antioxidant potentials [34].

\subsection{Phenolic Compounds}

Table 3 shows the flavonoid content of the samples analysed. In all of them, except the controls, the only phenolic compounds identified were narirutin and hesperidin, the latter in greater concentrations. This might see contradictory because in the flavonoid content of CFWW, the concentration of narirutin $(38.91 \mathrm{mg} / \mathrm{L})$ is greater than that of hesperidin $(33.09 \mathrm{mg} / \mathrm{L})$ [8].

Hesperidin levels fell to a statistically significant extent $(\mathrm{P}<0.05)$ between day 0 and day 24 , the type of packaging exercising a significant effect $(\mathrm{P}<0.05)$ in this respect. In the samples exposed to air the levels fell more than in the MA and vacuum-packed samples (from 10.44 and $10.36 \mu \mathrm{g} / \mathrm{g}$ of sample to 8.54 and $8.49 \mu \mathrm{g} / \mathrm{g}$ of sample for CFWW + TEO and CFWW + REO respecttively). The case of narirutin was somewhat similar, its value falling as time progressed $(\mathrm{P}<0.05)$, particularly in air-packed samples (from 5.77 and $5.81 \mu \mathrm{g} / \mathrm{g}$ of sample to 3.86 and $3.91 \mu \mathrm{g} / \mathrm{g}$ of sample for CFWW + TEO and CFWW + REO, respectively).

This behaviour has been related with the degree of oxidation and the antioxidative protective effect of the flavonoid. These antioxidant activities have been widely demonstrated, although the mechanism of such activity is not fully understood. Several explanations have been provided, among them the following: the sequestration of free radicals; hydrogen donation; metallic ion chelation; or the flavonoids even acting as substrate for radicals such as superoxide or hydroxyl $[35,36]$.

Thus in air packed the polyphenols would have reacted more strongly with the free radicals produced, leading to their diminution and lower concentration [24]. This idea was lent weight by the data obtained for the oxidation and concentration of hesperidin in the MA and vacuum packed samples, where there was, again, a correlation between the degree of oxidation and concentra- 
Table 3. Flavonoid content ( $\mu \mathrm{g} / \mathrm{g}$ of sample) of mortadellas formulated with citrus fibre washing water (CFWW) and spice essential oils, with different storage conditions, during 24 days of storage.

\begin{tabular}{|c|c|c|c|c|c|c|c|}
\hline \multirow{2}{*}{ Compound } & \multirow{2}{*}{ Sample } & \multirow{2}{*}{$\begin{array}{l}\text { Storage } \\
\text { conditions }\end{array}$} & \multicolumn{5}{|c|}{ Time (d) } \\
\hline & & & 0 & 6 & 12 & 18 & 24 \\
\hline \multirow{6}{*}{$\begin{array}{c}\text { Hesperidin } \\
(\mu \mathrm{g} / \mathrm{g} \text { sample })\end{array}$} & CFWW+TEO & Air & $10.44 \pm 0.04^{\mathrm{aA}}$ & $9.69 \pm 0.01^{\mathrm{bA}}$ & $9.01 \pm 0.00^{\mathrm{cA}}$ & $8.78 \pm 0.01^{\mathrm{dA}}$ & $8.54 \pm 0.03^{\mathrm{eA}}$ \\
\hline & CFWW+TEO & MA & $10.44 \pm 0.04^{\mathrm{aA}}$ & $9.82 \pm 0.05^{\mathrm{bB}}$ & $9.58 \pm 0.02^{\mathrm{cB}}$ & $9.02 \pm 0.03^{\mathrm{dB}}$ & $8.75 \pm 0.03^{\mathrm{eB}}$ \\
\hline & CFWW+TEO & Vacuum & $10.44 \pm 0.04^{\mathrm{aA}}$ & $9.95 \pm 0.04^{\mathrm{bC}}$ & $9.67 \pm 0.03^{\mathrm{cC}}$ & $9.15 \pm 0.04^{\mathrm{dC}}$ & $9.01 \pm 0.04^{\mathrm{eC}}$ \\
\hline & $\mathrm{CFWW}+\mathrm{REO}$ & Air & $10.36 \pm 0.05^{\mathrm{aA}}$ & $9.65 \pm 0.02^{\mathrm{bD}}$ & $9.11 \pm 0.04^{\mathrm{cD}}$ & $8.81 \pm 0.02^{\mathrm{dA}}$ & $8.49 \pm 0.02^{\mathrm{eA}}$ \\
\hline & $\mathrm{CFWW}+\mathrm{REO}$ & MA & $10.36 \pm 0.05^{\mathrm{aA}}$ & $9.75 \pm 0.05^{\mathrm{bB}}$ & $9.63 \pm 0.02^{\mathrm{cE}}$ & $8.97 \pm 0.04^{\mathrm{dB}}$ & $8.78 \pm 0.01^{\mathrm{eB}}$ \\
\hline & $\mathrm{CFWW}+\mathrm{REO}$ & Vacuum & $10.36 \pm 0.05^{\mathrm{aA}}$ & $9.91 \pm 0.03^{\mathrm{bC}}$ & $9.72 \pm 0.02^{\mathrm{cC}}$ & $9.12 \pm 0.02^{\mathrm{dC}}$ & $8.98 \pm 0.02^{\mathrm{eC}}$ \\
\hline \multirow{6}{*}{$\begin{array}{c}\text { Narirutin } \\
(\mu \mathrm{g} / \mathrm{g} \text { sample })\end{array}$} & CFWW+TEO & Air & $5.77 \pm 0.02^{\mathrm{aA}}$ & $4.32 \pm 0.03^{\mathrm{bA}}$ & $4.18 \pm 0.04^{\mathrm{cA}}$ & $4.05 \pm 0.03^{\mathrm{dA}}$ & $3.86 \pm 0.01^{\mathrm{eA}}$ \\
\hline & CFWW+TEO & MA & $5.77 \pm 0.02^{\mathrm{aA}}$ & $4.68 \pm 0.02^{\mathrm{bB}}$ & $4.35 \pm 0.03^{\mathrm{cB}}$ & $4.15 \pm 0.02^{\mathrm{dB}}$ & $4.06 \pm 0.02^{\mathrm{eB}}$ \\
\hline & CFWW+TEO & Vacuum & $5.77 \pm 0.02^{\mathrm{aA}}$ & $4.86 \pm 0.04^{\mathrm{bC}}$ & $4.59 \pm 0.03^{\mathrm{cC}}$ & $4.29 \pm 0.02^{\mathrm{dC}}$ & $4.12 \pm 0.03^{\mathrm{eC}}$ \\
\hline & \multirow{3}{*}{$\begin{array}{l}\text { CFWW+REO } \\
\text { CFWW+REO } \\
\text { CFWW+REO }\end{array}$} & Air & $5.81 \pm 0.03^{\mathrm{aA}}$ & $4.31 \pm 0.01^{\mathrm{bA}}$ & $4.22 \pm 0.01^{\mathrm{cA}}$ & $4.09 \pm 0.04^{\mathrm{dA}}$ & $3.91 \pm 0.04^{\mathrm{eA}}$ \\
\hline & & MA & $5.81 \pm 0.03^{\mathrm{aA}}$ & $4.71 \pm 0.02^{\mathrm{bB}}$ & $4.40 \pm 0.02^{\mathrm{cB}}$ & $4.19 \pm 0.02^{\mathrm{dB}}$ & $4.03 \pm 0.02^{\mathrm{eB}}$ \\
\hline & & Vacuum & $5.81 \pm 0.03^{\mathrm{aA}}$ & $4.85 \pm 0.05^{\mathrm{bC}}$ & $4.68 \pm 0.01^{\mathrm{cD}}$ & $4.22 \pm 0.02^{\mathrm{dD}}$ & $4.16 \pm 0.02^{\mathrm{eC}}$ \\
\hline
\end{tabular}

For a same compound, values followed by the same small letter within the same line are not significantly different $(P>0.05)$ according to Tukey's Multiple Range Test, For a same compound, values followed by the same capital letter within the same column are not significantly different $(P>0.05)$ according to Tukey's Multiple Range Test.

tion of the flavonoid.

The rest of the phenolic compounds present in the citrus fibre washing water, including caffeic acid, ferulic acid, $p$-coumaric acid or the flavonoids eriocitrin, or neohesperidin or terpenes present in thyme or rosemary essential oil such as carvacrol or thymol, were gradually lost during the elaboration process.

\subsection{Sensory Evaluation}

Figure 1 show the results obtained for the sensory analysis carried out at the end (day 24) of the assay. The vacuum packed CFWW + TEO sample scored best for appearance, while the air and MA packed control samples were least appreciated in this respect. As regards colour intensity, vacuum packed CFWW + REO and CFWW + TEO samples showed the highest values. As regards shine, these were differences between the appreciation of this property as measured by panellists and instrumental means, the panellists detecting greater shine in vacuum packed CFWW + REO sample, while the instrumental measurement of $\mathrm{L}^{*}$ showed similar values for all the samples.

In general, except for hue, juiciness and hardness, greater differences were seen between the air packed control samples for all the parameters considered, which were more poorly marked than the samples with added
CFWW + REO and CFWW + TEO. The fat character, acid taste, salt taste and odour values were very similar in all cases. It should be noted that, despite the marked aroma of thyme or rosemary, this was not found

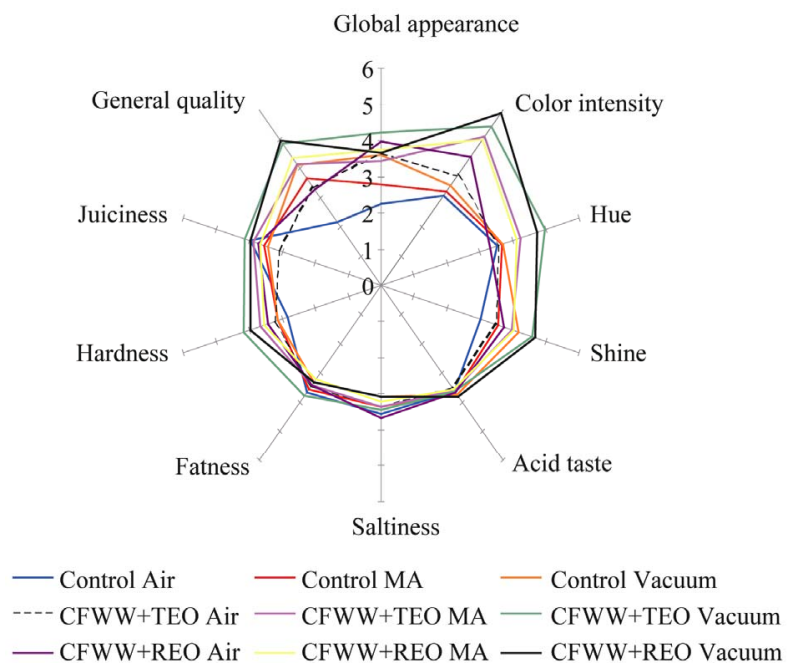

Figure 1. Results of the sensory evaluation (quantitative descriptive analysis) carried out in the samples formulated with different citrus fibre washing water (CFWW) and thyme or rosemary essential oil. 
unpleasant by the panellists, who valued the samples containing these essential oils almost equally with the controls. The best appreciated sample was the vacuum packed CFWW + REO sample, and the least acceptable the control sample exposed to air.

\subsection{Microbiological Analysis}

In our experiment, no Enterobacteria or psychrotrophic bacteria were found in any of the treatments (control, CFWW + TEO and CFWW + REO), regardless of packaging method or time of storage, probably as a result of the effectiveness of the cooking and aseptic slicing process, together with the presence of sodium chloride in the products. Figures 2(a) and 2(b) show the effect of treatments, packaging conditions and time on the growth of aerobic and lactic bacteria. On day 0 , the CFWW + TEO and CFWW + REO samples showed lower lactic acid bacteria and aerobic bacteria growth values $(\mathrm{P}<$ 0.05 ) than the control samples in all three types of packaging with no statistically significant differences $(\mathrm{P}>$ 0.05 ) between the CFWW + TEO and CFWW + REO samples. On day 12 , the vacuum packed control sample, CFWW + TEO and CFWW + REO vacuum packed samples showed the lowest $(\mathrm{P}<0.05)$ aerobic bacteria counts $(3.79,3.62$ and $3.51 \log \mathrm{cfu} / \mathrm{g}$, respectively) and the lowest $\mathrm{P}<0.05)$ lactic acid bacteria counts $(2.97$, 2.63 and $2.54 \log \mathrm{cfu} / \mathrm{g}$, respectively). The air packed control sample showed the highest $(\mathrm{P}<0.05)$ aerobic bacteria and lactic acid bacteria counts in all the samples. At the end of experiment ( 24 days) the vacuum packed CFWW + TEO and vacuum packed CFWW + REO samples showed the lowest aerobic bacteria and lactic acid bacteria counts $(P<0.05)$, with no statistically significant differences $(\mathrm{P}>0.05)$ between them. The air packed control sample showed the highest $(\mathrm{P}<0.05)$ aerobic bacteria and lactic acid bacteria counts in both the control and treated samples.

The combination of a $\mathrm{pH}$ of around 6.0 and the heat treatment, as well as storage at a $4^{\circ} \mathrm{C}$, seems to be sufficient to produce a microbiologically stable product, which remains stable for at least 24 days of storage. In all the samples, the total aerobic bacteria and lactic acid counts at the end of the experiment were below those considered as representing a degraded product (high viscosity, off-colour, off-flavours). As in the case of lipid oxidation, the antimicrobial activity might be attributed to the bioactive compounds present in both fibre and essential oils, especially polyphenols and terpenes.

\section{Conclusions}

The addition of citrus fibre washing water and thyme or rosemary essential oil is a technologically viable alter-

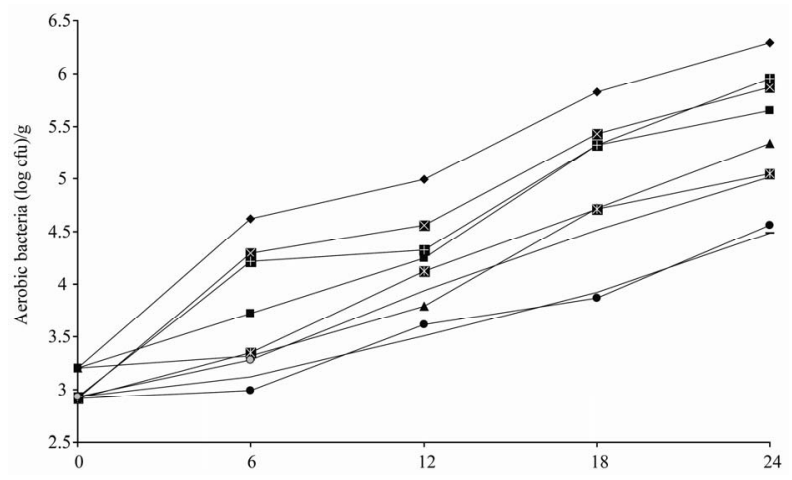

(a)

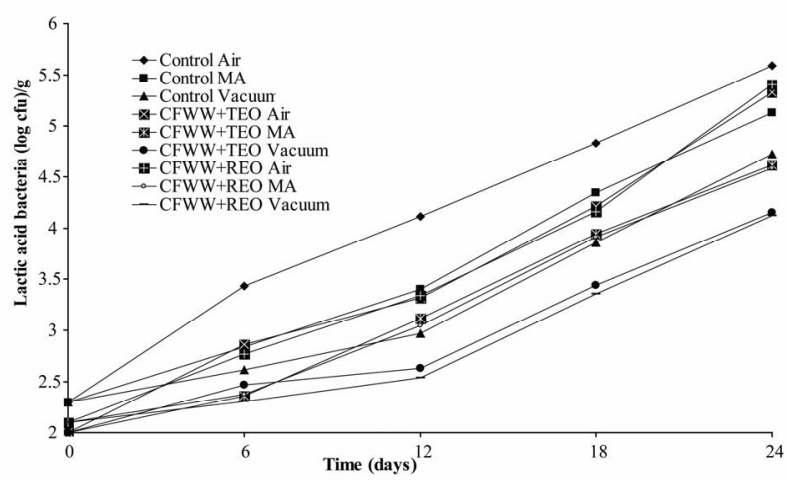

(b)

Figure 2. Evolution of counts of aerobic bacteria (a) and lactic acid bacteria (b) in mortadellas formulated with citrus fibre washing water and thyme or rosemary essential oil, with dif- ferent storage conditions, during 24 days of storage.

native in emulsified meat products, since they improve customer acceptance and have desirable effects as regards oxidative stability and reduced microbial growth, which contributes to prolonging their shelf-life and the "natural" image of the products is improved. Some polyphenolic compounds, such as flavonoids, are also introduced with the citrus fibre washing water and this may have a beneficial effect on human health since they have been linked with the prevention of various illnesses.

\section{Acknowledgements}

We are grateful to the CAM "Caja de Ahorros del Mediterráneo" for the research scholarship awarded to one of the authors (MVM).

\section{REFERENCES}

[1] M. Viuda-Martos, Y. Ruiz-Navajas, J. Fernández López and J. A. Pérez-Álvarez, "Effect of Adding Citrus Waste Water, Thyme and Oregano Essential Oil on the Chemical, Physical and Sensory Characteristics of a Bologna 
Sausage," Innovative Food Science and Emerging Technology, Vol. 10, No. 4, 2009, pp. 655-660.

doi:10.1016/j.ifset.2009.06.001

[2] E. Sánchez-Zapata, E. Fuentes-Zaragoza, J. FernándezLópez, E. Sendra, E. Sayas, C. Navarro and J. A. PérezAlvarez, "Preparation of Dietary Fiber Powder from Tiger Nut (Cyperus esculentus) Milk ("Horchata") ByProducts and Its Physicochemical Properties," Journal of Agricultural and Food Chemistry, Vol. 57, No. 17, 2009, pp. 7719-7725.

[3] K. N. Englyst, S. Liu and H. N. Englyst, "Nutritional Characterization and Measurement of Dietary Carbohydrates," European Journal of Clinical Nutrition, Vol. 61, No. 1, 2007, pp. 19-34. doi:10.1038/sj.ejen.1602937

[4] L. M. Ohr, "Facets of Ageing," Food Technology, Vol. 61, No. 12, 2007, pp.79-84.

[5] J. A. Pérez-Álvarez, "Los alimentos del bienestar: La alimentación del siglo XXI," Industria Alimentaria, Vol. 2, No. 3, 2008, p. 54.

[6] M. Estévez and R. Cava, "Effectiveness of Rosemary Essential Oil as an Inhibitor of Lipid and Protein Oxidation: Contradictory Effects in Different Types of Frankfurters," Meat Science, Vol. 72, No. 2, 2006, pp. 348-355. doi:10.1016/j.meatsci.2005.08.005

[7] M. Estévez, D. Morcuende, J. Ventanas and R. Cava, "Effect of Addition of Sage and Rosemary Extracts on the Oxidative Stability of Different Types of Lives Pates," Proceedings of 50th International Congress of Meat Science and Technolog,. Helsinki, Finland, 2004, pp. 194-195.

[8] M. Viuda-Martos, J. Fernández-López, E. Sayas-Barberá, E. Sendra and J. A. Pérez-Álvarez, "Physico-Chemical Characterisation of the Orange Juice Waste Water of a Citrus Co-Product," Journal of Food Processing and Preservation, 2010, In Press. doi:10.1111/j.1745-4549.2009.00450.x

[9] M. Viuda-Martos, Y. Ruiz-Navajas, J. Fernández-López and J. A. Pérez-Alvarez, "Spices as Functional Foods: A Review," Critical Reviews in Food Science and Nutrition, 2010, In Press.

[10] X. Ormancey, S. Sisalli and P. Coutiere, "Formulation of Essential Oils in Functional Perfumery," Parfums, Cosmetiques, Actualites, Vol. 157, 2001, pp. 30-40.

[11] G. Reglero, P. Frial, A. Cifuentes, M. R. García-Risco, L. Jaime, F. R. Marín, V. Palanca, A. Ruiz-Rodríguez, S. Santoyo, F. J. Señorans, C. Soler-Rivas, C. Torres and E. Ibañez, "Meat-Based Functional Foods for Dietary Equilib- Rium Omega-6/Omega-3," Molecular Nutrition and Food Research, Vol. 52, No. 10, 2008, pp.1153-1161. doi:10.1002/mnfr.200700367

[12] J. M. Fernández-Ginés, J. Fernández-López, E. SayasBarbera, E. Sendra and J. A. Pérez-Alvarez, "Effect of Storage Conditions on Quality Characteristics of Bologna Sausages Made with Citrus Fibre," Journal of Food Science, Vol. 68, No. 2, 2003, pp. 710-715. doi:10.1111/j.1365-2621.2003.tb05737.x
[13] M. C. Hunt, J. C. Acton, R. C. Benedict, C. R. Calkins, D. P. Cornforth, L. E. Jeremiah, D. P. Olson, C. P. Salm, J. W. Savell and S. D. Shivas, "Guidelines for Meat Color Evaluation," American Meat Science Association and National Live Stock and Meat Board, Chicago, USA, No. 191, pp. 1-12.

[14] M. C. Bourne, "Texture Profile Analysis," Food Technology, Vol. 32, 1978, pp. 62-72.

[15] J. A. Buege and S. D. Aust, "Microsomal Lipid Peroxidation," Methods in Enzymology, Vol. 52, 1978, pp. 302-304. doi:10.1016/S0076-6879(78)52032-6

[16] Institute of Food Technologists, "Sensory Evaluation Guide for Testing Food and Beverage Products," Journal of Food Science, 1981, pp. 50-59.

[17] ASTM, "Physical Requirements. Guidelines for Sensory Evaluation Laboratories," American Society for Testing and Materials, Philadelphia, 1986.

[18] ISO, "Sensory Analysis General Guidance for the Design of Test Rooms," Ref. nr ISO International Standard 8589, Genevè: International Organization for Standardization, 1988.

[19] R. C. Storer, Ed., "Standard and Sensory Evaluation of Materials and Products," ASTM Manual Series, American Society for Testing and Materials, Philadelphia, 1988.

[20] A. A. Afifi and S. P. Azen, "Statistical Analysis. A Computer Oriented Approach," Academic, London, 1979.

[21] J. A. Pérez-Alvarez and J. Fernández-López, "Chemistry and Biochemistry of Color in Muscle Foods," In: Y. H. Hui, W. K. Nip, L. M. L. Nollet, G. Paliyath and B. K. Simpson, Eds, Food Biochemistry and Food Processing, Blackwell Publishing, Ames, 2006, pp. 337-350. doi:10.1002/9780470277577.ch15

[22] M. L. García, E. Caceres and M. D. Selgas, "Utilisation of Fruit Fibres in Conventional and Reduced-Fat CookedMeat Sausages," Journal of Food Science and Agricultural, Vol. 87, No. 4, 2007, pp. 624-631. doi:10.1002/jsfa. 2753

[23] J. Fernández-López, E. Sayas-Barberá, C. Navarro, E. Sendra and J. A. Pérez-Álvarez, "Antioxidant and Antibacterial Activities of Natural Extracts: Application on Cooked Meat Balls," Meat Science, Vol. 69, No. 3, 2005, pp. 371-380. doi:10.1016/j.meatsci.2004.08.004

[24] M. Viuda-Martos, Y. Ruiz-Navajas, J. Fernández López and J. A. Pérez-Alvarez, "Effect of Orange Dietary Fibre, Oregano Essential Oil and Packaging Conditions on Shelf-Life of Bologna Sausages," Food Control, Vol. 21, No. 4, 2010, pp. 436-443. doi:10.1016/j.foodcont.2009.07.004

[25] S. Cofrades, A. Serrano, J. Ayo, M. T. Solas, J. Carballo and F. Jiménez-Colmenero, "Restructured Beef with Different Proportions of Walnut as Affected by Meat Particle Size," European Food Research and Technology, Vol. 218, No. 3, 2004, pp. 230-236. doi:10.1007/s00217-003-0808-y

[26] G. A. Dykes, T. E. Cloete and A. Von Holy, "Quantifica- 
tion of Microbial Populations Associated with the Manufacture of Vacuum-Packaged, Smoked Vienna Sausages," International Journal of Food Microbiology, Vol. 13, No. 4, 1991, pp. 239-248. doi:10.1016/0168-1605(91)90081-Y

[27] T. Keokamnerd, J. C. Acton, I. Y. Han and P. L. Dawson, "Effect of Commercial Rosemary Oleoresin Preparations on Ground Chicken Thigh Meat Quality Packaged in a High-Oxygen Atmosphere," Poultry Science, Vol. 87, No. 1, 2008, pp. 170-179. doi:10.3382/ps.2007-00066

[28] J. Fernández-López, M. Viuda-Martos, E. Sendra, E. Sayas-Barberá, C. Navarro and J. A. Pérez-Alvarez, "Orange Fibre as Potential Functional Ingredient for Drycured Sausages," European Food Research and Technology, Vol. 226, No. 1-2, 2007, pp. 1-6. doi:10.1007/s00217-006-0501-Z

[29] J. Fernández-López, E. Sendra, E. Sayas-Barberá, C. Navarro and J. A. Pérez-Alvarez, "Physico-Chemical and Microbiological Profiles of 'Salchichón' (Spanish dry fermented sausage) Enriched with Orange Fiber," Meat Science, Vol. 80, No. 2, 2008, pp. 410-417. doi:10.1016/j.meatsci.2008.01.010

[30] B. Zhou, L. M. Wu, L. Yang and Z. L. Liu, "Evidence for Alpha-Tocopherol Regeneration Reaction of Green Tea Poly-Phenols in SDS Micelles," Free Radical Biology and Medicine, Vol. 38, No. 1, 2005, pp. 78-84. doi:10.1016/j.freeradbiomed.2004.09.023
[31] E. Finotti and D. Di Majo, "Influence of Solvents on the Antioxidant Property of Flavonoids," Die Nahrung, vol. 47, No. 3, 2003, pp. 186-187. doi:10.1002/food.200390043

[32] M. Viuda-Martos, Y. Ruiz-Navajas, E. SánchezZapata, J. Fernández-López and J. A. Pérez Alvarez, "Antioxidant Activity of Essential Oils of Five Spice Plants Widely Use in Mediterranean Diet," Flavour and Fragrance Journal, Vol. 25, No. 1, 2010, pp. 13-19. doi:10.1002/ffj.1951

[33] G. Ruberto and M. T. Baratta, "Antioxidant Activity of Selected Essential Oils Components in Two Lipid Model System," Food Chemistry, Vol. 69, No. 1, 2000, pp. 167174. doi:10.1016/S0308-8146(99)00247-2

[34] K. F. El-Massry, A. H. El-Ghorab and A. Farouk, "Antioxidant Activity and Volatile Components of Egyptian Artemisia judaica L.," Food Chemistry, Vol. 79, No. 3, 2002, pp. 331-336. doi:10.1016/S0308-8146(02)00164-4

[35] M. Al-Mamary, A. Al-Meeri and M. Al-Habori, "Antioxidant activities and total phenolics of different types of honey," Nutrition Research, Vol. 22, No. 9, 2002, pp. 1041-1047. doi:10.1016/S0271-5317(02)00406-2

[36] J. G. Sebranek, V. J. H. Sewalt, K. L. Robbinsa and T. A. Houser, "Comparison of a Natural Rosemary Extract and BHA/BHT for Relative Antioxidant Effectiveness in Pork Sausage," Meat Science, Vol. 69, No. 2, 2005, pp. 289296. doi:10.1016/j.meatsci.2004.07.010 